\title{
ECONOMIC POTENTIAL OF "GREEN" ECONOMY IN DEVELOPMENT OF RURAL TERRITORIES
}

\author{
Tatjana Tambovceva ${ }^{1}$, Dr.oec.; Maria Tereshina ${ }^{2}$, Dr.oec. \\ ${ }^{1}$ Riga Technical University, ${ }^{2}$ Federal State Budget Education Institution of Higher Education \\ "Kuban State University"
}

\begin{abstract}
The purpose of the study was to examine the theoretical and methodological aspects of the economic potential of a "green" economy in the rural areas development. The research approach implies a holistic cognitive design that allows to explain and predict the development of the "green" economy constructive potential for the sustainable development of rural areas. As a result, on the basis of theoretical sources, the main characteristics of the rural development model were identified on the principles of a "green" economy, the successful international experience in implementing "green" economy practices in rural areas was generalized and the conditions necessary for realizing it were determined. Considering the significant differentiation of rural areas, the directions for realizing the "green" economy potential for each type of rural territory were concretized: economically integrated, transitional and depressed. On the example of the model region, there was proposed an approach allowing to assess the feasibility to realize the economic potential of a "green" economy and determine priority areas for private financing and state support. The integral indicator of resource security is a set of interrelated blocks formed as a result of the systemic interaction of external and internal factors. In general terms the indicator includes natural, technical, infrastructural, demographic, financial and investment components, as well as the social readiness resources of local communities for the "green" economy development (socio-psychological, regulatory, scientific, methodological). The research methodology included the analysis of the reports, studies and publications on various aspects of the "green" economy development in rural areas, case analysis, statistical data study, system and comparative analysis, expert surveys, cluster and variance analysis.
\end{abstract}

Key words: "green" economy, rural areas, local resources.

JEL code: Q01, R10

\section{Introduction}

Despite the prevalence of the urbanization process throughout the world, the importance of rural areas remains enormous and is determined by the growing importance of the functions they perform, especially environmental ones. In modern scientific discourse, considerable attention is paid to the search for the most effective socio-economic mechanisms for sustainable rural development. In different countries, there is a significant number of approaches and conceptual models, both at the level of theoretical developments and at the level of practical implementation of policies aimed at sustainable development of the agricultural sector and rural areas. At the same time, heterogeneity and significant differentiation of rural areas, as well as a significant variety of sectors of the "green" economy, objectively determine the lack of theoretical and methodological developments that adequately explain the formation of green "growth points" within the boundaries of rural areas, the trajectory of their development, and the relevance of the study of "green" growth constructive economic potential.

The hypothesis of the study is made by the provision that the basis for the formation of a modern sustainable development policy of rural areas is the identification and development of the economic potential of a "green" economy.

The research aim consisted of studying the economic potential of a "green" economy in the development of rural areas in theoretical and methodological aspects.

To achieve this specified goal, the following tasks were identified:

- on the basis of theoretical sources, to identify the main characteristics of the rural development model on the principles of a "green" economy; 
- to generalize the successful international experience in implementing the practices of a"green" economy in rural areas, to determine the conditions necessary for this;

- to outline the main possible directions for the "green" economy development in rural areas of various types;

- to propose an approach to assessing the resources of local communities in rural areas allowing to estimate the opportunities for realizing the economic potential of a "green" economy and to determine priority directions for private financing and state support on the example of a model region.

The research methodology included the analysis of the reports, studies and publications on various aspects of "green" economy development in rural areas, case analysis, statistical data study, system and comparative analysis, expert surveys, cluster and variance analysis.

The novelty of the research lies in the integration of separate scientific results into a coherent cognitive construction that will allow to describe, explain and predict the development of the green economy constructive potential for the sustainable development of rural areas.

\section{Research results and discussion}

\section{Problem statement. Theoretical insights}

The mechanisms of rural development have a dynamic nature, changing not only according to the strategies of various social and institutional structures and political forces, but also owing to changes of global trends relating to socio-economic development. Since rural areas are not closed, isolated spaces the technological and institutional changes characteristic of modern society on the whole to some extent affect the architecture of their socio-economic design.

Traditional approaches to the development of rural areas considered them mainly as a set of resources and a reservoir for the development of production processes in agriculture and recognized their providing and lagging character in comparison with urban (indisputable "poles of growth"). It can be said that, at the present time, as opposed to this approach, a new approach to rural development has been formed (Ploeg J., 2002; Guinjoan E. et.al, 2016). The focus of the new approach is more directed towards qualitative rather than quantitative parameters of rural areas development and takes into account specific local resources of domestic communities in the field of development, emphasizing environmental aspects. The new frontier that forms the basis for the sustainable development of rural areas is determined by the "green" and circular economy paradigms and integrates a whole range of research approaches, including a new theory of "rural networks" (Kristensen K., 2016; D'Amato D. et.al, 2017), which also includes institutional models of the eco and bio-economy (Marsden T., 2008).

The analysis of literary sources makes it possible to identify the main characteristics of the rural development model on the principles of the "green" economy. The necessity to introduce the principles of "green" economy into the economic practice of rural areas is determined, first of all, by the significant dependence of the rural economy on industries sensitive to the qualitative parameters of the environment, the presence of close integration links between natural, economic and social components and the increasing negative impact of agricultural production on the environment.

Unlike traditional environmental approach which implies, to a large extent, certain limitations of economic development in rural areas "green growth" serves as a catalyst for investment and innovation, creates new economic opportunities, serves as a basis for structural shifts in favour of 
resource-saving, technologically advanced industries and activities (Loiseau E. et.al, 2016; Melece L., 2016).

\begin{tabular}{|c|c|}
\hline $\begin{array}{l}\text { Goals of rural } \\
\text { development } \\
\text { management }\end{array}$ & $\begin{array}{l}\text { - Local resources use } \\
\text { - Diversification of activities through the "green" industries } \\
\text { development (RES development, waste recycling, eco-and } \\
\text { agrotourism, circular economy) } \\
\text { - New forms of cost reduction (resource-saving)) }\end{array}$ \\
\hline $\begin{array}{l}\text { The main drivers } \\
\text { of development }\end{array}$ & $\begin{array}{l}\text { - State support at national and regional level } \\
\text { - Political will at the local level } \\
\text { - Demand for ecological goods and services in rural areas } \\
\text { - Socio-ecological responsibility of business } \\
\text { - Deterioration of the environment }\end{array}$ \\
\hline $\begin{array}{l}\text { The account of } \\
\text { the particular } \\
\text { territory specifics }\end{array}$ & $\begin{array}{l}\text { - Emphasizing the importance of rural identity preservation and the } \\
\text { formation of local socio-ecological identity } \\
\text { - Comprehensive assessment of the resource potential of the territory } \\
\text { - The formation of points of "green" growth (ecoloci) with subsequent } \\
\text { diffusion of successful practices }\end{array}$ \\
\hline $\begin{array}{l}\text { Dominant sectors } \\
\text { of the economy }\end{array}$ & $\begin{array}{l}\text { - The central place - intensive agriculture of the traditional type with the } \\
\text { introduction of environmentally friendly technologies } \\
\text { - The central place - organic agriculture } \\
\text {-Diversification of the local economy on the basis of "green" branches } \\
\text { and industries and the circular economy }\end{array}$ \\
\hline $\begin{array}{l}\text { The role of local } \\
\text { communities }\end{array}$ & $\begin{array}{l}\text {-The central place - network local structures } \\
\text { - Rural development is understood as a multi-factor process } \\
\text {-The central place - the concept of partnership }\end{array}$ \\
\hline $\begin{array}{l}\text { Features of } \\
\text { institutional } \\
\text { structures }\end{array}$ & $\begin{array}{l}\text {-Active forms of intersectoral interaction } \\
\text { - Multilevel management }\end{array}$ \\
\hline
\end{tabular}

Fig. 1. The model of the "green" development in rural areas: the main characteristics (compiled by the authors)

Individual aspects of this issue in various contexts have been studied quite well. The problems of sustainable development of rural areas, strategies and models for counteracting negative processes are the subject of research in almost all countries(Horlings L. G., 2014; Yashalova N., 2014). Studies on "green" investment and "green" innovations in rural development are mainly research and methodological developments of international organizations (Final Report..., 2016; Green economy opportunities..., 2017; OESD, 2017). A large layer of research refers to organic farming (Willer $H_{.}$, 2017) and eco-settlements(Christian D., 2003; Gilman R., 1991; Petrov V., 2008).

Nevertheless, the existence of certain "gaps" between the challenges and threats constantly arising in the socio-economic space of rural areas and the theoretical constructions allowing to explain the changes raises the question of the new conceptual schemes development and appropriate analytical tools for the study of the new reality of the rural areas development in the context of a "green" economy.

\section{Practical efforts in the field of rural development on the basis of "green" growth}

Currently, a large number of rural development projects based on the principles of a "green" economy are being implemented around the world, but the most systematic nature of this process can be seen in the European Union. The "green" development of the rural economy is one of the priority activities of the European Rural Development Network (ENRD) for the period from 2014 
to 2020 and is related to the objectives of restoring, preserving and strengthening the ecosystems of rural areas, as well as promoting more efficient use of resources and supporting the transition to a low-carbon and climate neutral economy in agricultural, food and forestry sectors (ENRD, 2017; Pitkanen K. et al, 2016; Melece L., 2008).

An important tool to promote the introduction of a "green" economy in rural areas is the Rural Development Programmes (RDPs). The main activities supported by such programmes include green technologies in waste management, sustainable water management, eco-tourism, sustainable buildings, services and infrastructure investments in natural capital, for example, wetlands, forests or floodplains, "green" infrastructure, providing ecosystem services, sustainable management of agriculture and forestry, adaptation to climate change, improving energy efficiency and developing renewable energy, green public procurement. The fastest growing sector of the "green" economy in rural areas is organic agriculture (Table 1).

The main indicators of the organic farming development in the world

Table 1

\begin{tabular}{|l|c|c|c|c|c|}
\hline \multicolumn{1}{|c|}{ Region } & $\begin{array}{c}\text { Organic } \\
\text { area (ha) }\end{array}$ & $\begin{array}{c}\text { Shares of the } \\
\text { global organic } \\
\text { farmland area, \% }\end{array}$ & $\begin{array}{c}\text { Organic share of } \\
\text { total farmland } \\
\text { area, \% }\end{array}$ & $\begin{array}{c}\text { Growth } \\
\text { 2014- } \\
\mathbf{2 0 1 5} \text { \% }\end{array}$ & $\begin{array}{c}\text { Number of } \\
\text { organic } \\
\text { producers }\end{array}$ \\
\hline Africa & 1683482 & 3 & 0,1 & $+33,5$ & 719720 \\
\hline Asia & 3965289 & 8 & 0.2 & $+11,1$ & 851016 \\
\hline Europe & 12716969 & 25 & 2.5 & $+8,2$ & 349261 \\
\hline $\begin{array}{l}\text { Latin } \\
\text { America }\end{array}$ & 6744722 & 13 & 0.9 & $-1,3$ & 457677 \\
\hline $\begin{array}{l}\text { North } \\
\text { America }\end{array}$ & 2973886 & 6 & 0.7 & $+21,0$ & 19138 \\
\hline Oceania & 22838513 & 45 & 5.4 & $+23,2$ & 23728 \\
\hline Total & 50919006 & 100 & 1,1 & $+14,7$ & 2420540 \\
\hline
\end{tabular}

Source: author's calculations based on the FiBL survey, 2017

At the same time, it should be noted that although the development indicators of this sector of the "green" economy differ significantly across the countries, nevertheless, they demonstrate the considerable economic potential (Table 2).

Comparative indicators of the organic agriculture development in Latvia

Table 2 and Russia

\begin{tabular}{|l|c|c|c|c|}
\hline & $\begin{array}{c}\text { Organic } \\
\text { area, ha }\end{array}$ & $\begin{array}{c}\text { Organic share of total } \\
\text { agricultural land, \% }\end{array}$ & $\begin{array}{c}\text { Number of organic } \\
\text { producers }\end{array}$ & $\begin{array}{c}\text { Organic retail sales, } \mathbf{m} \\
\text { euro (2011) }\end{array}$ \\
\hline Latvia & 231608 & 12,8 & 3634 & 4 \\
\hline Russia & 385140 & 0,2 & 82 & 120 \\
\hline
\end{tabular}

Source: author's calculations based on the FiBL \& IFOAM, 2017

It is worth mentioning that in many European countries it is the state socio-structural directives "from above" that created the "initial model" for the "green" development of the rural economy. That is why the role of national governments with their significant administrative and financial resources in the process of transforming the existing economic models towards their "greening" cannot be overemphasized. Changes in legislation and policy, investment of public funds in the development of "green" industries, are considered to be important tools for the transition to a "green" economy, which is underscored by many leading experts. But recently, at the level of individual rural communities, there have been a sufficient number of cost-effective projects initiated "from below" with minimal financial support from the state or without it. The main conditions conducive to this process include the growing demand for "green" goods and services of 
rural areas, the growing willingness of consumers to pay for ecosystem services and the use of economic opportunities created by this demand, the revival or revitalization of the traditions of cooperation and collaboration within local communities, the improvement of social capital.

Basing on the generalization of the experience of implementing successful projects and programs of "green" development in rural areas, it is possible to identify the most characteristic features that allow to fully realize their economic potential: focus on the already existing demand in the market or social problems (Tereshina M., 2014), the balance of environmental, social and economic goals, their clarity and economic validity, innovativeness, the availability of sustainable network communications and transparent intersectoral interaction, the diversification of financial sources, adaptability to changes in external conditions, the availability of educational programs, the control of planned and actual indicators, the translation of successful experience and results, the formation of socio-ecological identity and a new ecological mentality, the norms and level of trust creating between members of the local community, as well as information, technologies and the image of the territory.

\section{The basic directions of economic potential development of "green" growth in rural areas of various types}

Significant differentiation of rural areas makes it necessary to identify specific directions for realizing the "green" economy potential for each type of rural area. In most countries of the world, the criterion for the division of urban and rural areas is the population, the density of settlement and the nature of employment. As defined by the Organization for Economic Cooperation and Development (OECD), rural areas cover the population, land and other resources of the open landscape and small settlements outside the immediate economic areas of influence of major urban centres. The OECD typology includes the following types of rural areas.

1) Economically integrated territories in close proximity to economic centres are characterized by relatively high population density, significant supply of jobs, and well-developed infrastructure. In these areas, the preservation of ecological balance and the protection of the natural heritage are of primary importance. Despite good production and marketing conditions, agricultural production in these areas is constrained by high prices for land.

2) Transitional territories with medium development. They are located in places connected with transport highways. These regions are highly dependent on agriculture and related industries. The opportunities for their development are determined by two factors: first, the growth rates in the production structure and agriculture, and secondly, the development of industries that create alternative employment opportunities for the population.

3) Far from the centres of economic activity. Such regions are characterized by low population density, low income and high dependence on agriculture, an unfavourable demographic structure. Opportunities for economic development are very limited, which makes it possible to characterize them as depressive.

Depending on the type of rural area, various directions for realizing the potential of "green" growth are possible (Table 3 ). 
The directions of the "green" economy development depending on the type of rural area (compiled by the authors)

\begin{tabular}{|l|l|}
\hline $\begin{array}{c}\text { Type of rural } \\
\text { area }\end{array}$ & \multicolumn{1}{|c|}{ Directions of "green" development } \\
\hline $\begin{array}{l}\text { Economically } \\
\text { integrated }\end{array}$ & $\begin{array}{l}\text { Waste processing, development of resource and energy saving technologies in housing and } \\
\text { communal services, development of environmentally friendly modes of transport, } \\
\text { development of technologies and RES production, introduction of resource-saving } \\
\text { technologies based on intensive forms of production and processing of agricultural products }\end{array}$ \\
\hline Transitional & $\begin{array}{l}\text { Organic agriculture, agrarian tourism, development of renewable energy sources, } \\
\text { aquaculture, afforestation }\end{array}$ \\
\hline Depressive & $\begin{array}{l}\text { Provision of local communities with energy resources based on local renewable energy } \\
\text { sources, development of organic agriculture, ecological tourism, preservation of landscapes, } \\
\text { forest and meadow lands, use of labour potential of local communities to produce products } \\
\text { from local natural sources of raw materials. }\end{array}$ \\
\hline
\end{tabular}

Naturally, the impulses for the "green" economy development are formed depending on the resource potential and specific conditions prevailing in the local communities of rural areas, with their further distribution.

In this regard, it seems interesting to develop an approach to assessing the resources of local communities in rural areas allowing to estimate the feasibility of the economic potential of the "green" economy. The actualization of this approach is also connected with the fact that the allocation of the most resource-intensive rural communities will allow to determine the priority directions for private financing and state support.

\section{The assessment of the "green" economy economic potential in the context of the resource capabilities of local communities (case-study of the Krasnodar region)}

The choice of the Krasnodar region as an object of study is determined by the fact that this is one of the most well-known agricultural regions where practically all branches of agricultural production are developed and there are all types of rural territories. Agricultural lands which include arable land, hayfields, pastures, deposits, as well as lands under perennial plantations, occupy the largest part of the territory of the region - 4.721 .6 thousand hectares (62.5\%), and the rural population is more than half of the total population of the region. At the same time, the region has a significant natural and resource potential for the development of renewable energy, ecological tourism, organic agriculture and other important areas of the green economy. Risks of sustainable development of the rural areas in the region are related to the issues of food security, limited offer of natural and energy resources, qualified labour, a low level of innovative and modern technologies use, a strong dependence on the environmental quality and increasing vulnerability to climate change.

The strategy of social and economic development of the Krasnodar region, which is currently being developed as a strategic goal positions the Krasnodar region as one of the "leading regions of the smart and green agribusiness development". It seems that the basis for achieving this goal should be complex and systemic integration into the management system of methods, tools and principles of the "green" economy.

Under the resources of the local community in the development of the "green" economy development we understood the complex indicator which includes current resource opportunities, as well as possible directions of their use in order to obtain additional social, economic and environmental effects. This indicator is a set of interrelated resource blocks formed as a result of the systemic interaction of external and internal factors. In general terms, this indicator includes 
natural, technical, infrastructural, demographic, financial and investment components, as well as resources for social readiness of local communities to develop a "green" economy (sociopsychological, regulatory, scientific and methodological).

The assessment of the natural and technical, infrastructural, demographic and financial resources of the local rural communities was carried out on the basis of a quantitative indicators system selected and verified by means of peer review, corresponding to the following criteria: the reflection of the basic resources of the "green" economy development, the compliance with the objectives of "green" development, the possibility of the resource management at the local and regional levels, the availability of information on resources (availability of relevant indicators in the system municipal statistics), the ability to measure resources based on the objective quantitative data (Table 4).

The components of the integrated indicator of the rural community resources in the "green" economy development

\begin{tabular}{|l|l|}
\hline $\begin{array}{l}\text { Integral indicator } \\
\text { component }\end{array}$ & \multicolumn{1}{c|}{ Components } \\
\hline $\begin{array}{l}\text { Natural and } \\
\text { technical } \\
\text { resources }\end{array}$ & $\begin{array}{l}\text { The total solar radiation on the horizontal surface in the territory of the municipality, } \\
\text { the average annual wind speed, the annual volume of waste generated, the forest } \\
\text { cover of the territory, the specially protected natural areas, the agricultural land area, } \\
\text { the amount of pollutants discharged from all stationary sources }\end{array}$ \\
\hline $\begin{array}{l}\text { Infrastructure } \\
\text { resources }\end{array}$ & $\begin{array}{l}\text { The number of waste recycling enterprises, the length of public roads of local } \\
\text { importance owned by municipalities at the end of the year, the proportion of the } \\
\text { length of public roads of local importance that do not meet regulatory requirements } \\
\text { in the total length of public roads of local significance, the proportion of the } \\
\text { population settlements with no regular bus (rail) service with the administrative } \\
\text { centre in the total population, the specific amount of electricity consumption per } \\
\text { resident, the specific value of thermal energy consumption per 1 sq. km. m of the } \\
\text { total area, the number of places in collective accommodation facilities }\end{array}$ \\
\hline $\begin{array}{l}\text { Demographic } \\
\text { resources }\end{array}$ & $\begin{array}{l}\text { The average annual number of permanent population, the number of able-bodied } \\
\text { population, natural population growth }\end{array}$ \\
\hline $\begin{array}{l}\text { Financial and } \\
\text { investment } \\
\text { resources }\end{array}$ & $\begin{array}{l}\text { Surplus / deficit of the local budget, current (operational) costs for environmental } \\
\text { protection, including payment for environmental protection services, the volume of } \\
\text { investments in fixed assets (excluding budgetary funds) per capita, the number of } \\
\text { small and medium-sized businesses per 10 thousand people. }\end{array}$ \\
\hline
\end{tabular}

The resources of social readiness of rural communities for the transition to a "green" economy were analysed on the basis of qualitative scoring expert assessments on the following parameters:

- social and psychological willingness (density of network structures, the degree of social and ecological identity formation, the existence of the will and desire for social and environmental transformations, the activity of local interest groups in the environmental sphere, the existence and viability of local environmental initiatives, socio-environmental conflicts and the ability to their constructive solution);

- regulatory legal readiness characterizing the degree of completeness of the legal and regulatory framework necessary to implement reforms in the sphere of the "green" economy;

- scientific and methodological readiness characterizing the availability, as well as the degree of development of scientific and methodological materials (directions, recommendations, instructions) necessary for the implementation of socio-economic reforms, the degree of awareness of local communities about the state of the environment in the place of residence, the degree of reflection of environmental content in educational programs at educational institutions and the media).

The use of the cluster and variance analysis method made it possible, in the first approximation, to locate groups of high resource, medium resource and scarce resource territories. At the next 
stage the "weak links" of development which are actual for each territory, were diagnosed by comparison with the selected as a reference resource territory which will allow to update the forecasting tools and determine the directions and ways of management influence on the development of the "green" economy.

\section{Conclusions, proposals, recommendations}

1) Currently, a new model of sustainable development of rural areas is being formed. It is based on the concept of a "green" economy and has specific management objectives, functions that are performed by other branches of the economy, new development drivers and it is characterized by an increase in the role and significance of local communities and intersectoral and interlevel interaction in network institutional structures.

2) The following conditions are necessary for the successful implementation of the "green" economy economic potential in the development of rural areas: focus on existing demand in the sphere of market or social problems, the balance of environmental, social and economic goals, their clarity and economic validity, innovation, the availability of sustainable networks communications and transparent intersectoral interaction, the diversification of funding sources, the adaptability to changes in the external conditions, the availability of educational programs, the monitoring of planned and actual indicators, the broadcasting of successful experience and results, the formation of socio-ecological identity and a new ecological mentality, norms and the level of trust between members of the local community as well as information support.

3) Significant differentiation of rural areas objectively determines the need to specify the directions for realizing the "green" economy potential with respect to each type of rural territory: economically integrated, transitional and depressed.

4) An approach to assessing the resources of local communities in rural areas is proposed on the example of the model region, which allows to assess the possibilities for implementing the "green" economy economic potential and determine the priority areas for private financing and state support. The integral indicator of resource security is a set of interrelated blocks, formed as a result of the systemic interaction of external and internal factors. In general terms, the indicator includes natural, technical, infrastructural, demographic, financial and investment components, as well as resources of social readiness of local communities to develop a "green" economy (socio-psychological, regulatory, scientific and methodological).

5) Within the framework of this article, the proposed approach is considered in the most general form in order to demonstrate its capabilities for different types of rural territories. At the same time, the issues of adjusting and detailing the indicators depending on specific conditions of rural areas, their addition and clarification remain open and the authors will be grateful for any broader discussion, criticism and contributions to the topic under consideration.

The research was carried out with the support of the RFBR project No. 16-32-0016t "The development of a mechanism for implementing the concept of a "green" "economy in local practices of the domestic communities"

\section{Bibliography}

1. Christian, D. (2003). Creating a Life Together: Practical Tools to Grow Ecovillages and Intentional Communities. New Society Publishers, $272 \mathrm{p}$.

2. D'Amato, D, Droste, N, Allen, B, Kettunen, M, Lahtinenn K, Korhonen J, Leskinen P, Matthies, BD, Toppinen . A, (2017). Green, Circular, Bio Economy: a Comparative Analysis of Sustainability Avenues, Journal of Cleaner Production, Volume 168, pp. 716-734. 10.1016/j.jclepro.2017.09.053. 
3. Final Report of the ENRD Seminar: Promoting the Transition to a Green Economy September (2016). Retrieved: https://enrd.ec.europa.eu/sites/enrd/files/s2_ge_finalreport.pdf

4. Gilman R. (1991). Eco-Villages and sustainable settlements. SPb: The Center for Civil Initiatives. $266 \mathrm{p}$.

5. Green Economy Opportunities for Rural Europe Luxembourg: Publications Office of the European Union, (2017). Retrieved: https://enrd.ec.europa.eu/sites/enrd/files/publi-enrd-rr-23-2017-en.pdf

6. Green Growth Indicators. (2017). Retrieved: http://oe.cd/ggi

7. Guinjoan, E., Badia, A. \& Tulla, A. (2016). The New Paradigm of Rural Development. Theoretical Considerations and Reconceptualization Using the 'Rural Web'. Volume 71, pp. 495-500. 10.21138/bage.2279.

8. Horlings, L.G., Marsden, T.K. (2014). Exploring the "New Rural Paradigm" in Europe: Eco Economic Strategies as a Counterforce for Global Competitiveness Agenda. European Urban and Regional Studies, Volume 21, Issue 1, pp. 4-20. 10.1177/0969776412441934

9. Kristensen, D.K., Kjeldsen, C. \& Thorsoe, M. (2016). Enabling Sustainable Agro-Food Futures: Exploring Fault Lines and Synergies Between the Integrated Territorial Paradigm, Rural Eco-Economy and Circular Economy. Journal of Agricultural and Environmental Ethics, Volume 29, Issue 5, pp. 749765.10.1007/s10806-016-9632-9

10. Loiseau, E., Saikku, L., Antikainen, R., Droste, N., Hansjürgen, B., Pitkanen, K., Leskinen, P. , Kuikman, P. \& Thomsen, M. (2016). Green Economy and Related Concepts: an Overview. Journal of Cleaner Production, Volume 139, pp. 361-371. 10.1016/j.jclepro.2016.08.024

11. Marsden, T. \& Ploeg, J.D. van der. (2008). Preface: Exploring the Rural Web, The Dynamics of Regional Rural Development. Retrieved: http://edepot.wur.nl/368781

12. Melece, L. (2010). Environmentally Friendly Agriculture: Development Issues in Latvia. Socialiniai tyrimai/ Social Research, Volume 2, Issue 19, pp. 37-46.

13. Melece, L. (2016). Challenges and Opportunities of Circular Economy and Green Economy. 15th International Scientific Conference on Engineering for Rural Development Location: Jelgava, LATVIA Date: MAY 25-27, 2016 15th International Scientific Conference: Engineering For Rural Development Book Series: Engineering for Rural Development Volume 15, pp. 1162-1169.

14. Petrov, V.I. (2008). The Formation of Environmentally Sustainable Forms of Farming in Agricultural Lands: Background and Prospects // Actual problems of Russian Law. - M.: Moscow State Law Academy, Volume 1., pp. 126-134.

15. Pitkanen, K., Antikainen, R., Droste, N., Loiseau, E., Saikku, L., Aissani, L., Hansjürgens, B., Kuikman, P. , Leksinen, P. \& Thomsen, M. (2016). What Can be Learned from Practical Cases of Green Economy? Studies from Five European Countries. Journal of Cleaner Production, Volume 139, Issue 15, 139, pp. 666-676. DOI: 10.1016/j.jclepro.2016.08.071

16. Ploeg, J.D. van der, Long, A. \& Banks, J. (2002). Living Countrysides. Rural Development Processes in Europe: The State of the Art. Doetinchem: Elsevier, 2002. $231 \mathrm{p}$.

17. Promoting the Transition to a Green Economy ENRD Thematic Group Report. Retrieved: http://enrd.ec.europa.eu/thematic-work/greening-rural-economy/transition-green-economy_en

18. Tereshina, M.V. \& Degtyareva, I.N. (2014). The Formation and Development of Organic Products in Markets New Economic Conditions: Regional Aspects. Theory and Practice of Social Development. No. 15. pp. 102105.

19. Willer, H. \& Lernoud, J. (Eds.) (2017). The World of Organic Agriculture. Statistics and Emerging Trends 2017. Research Institute of Organic Agriculture (FiBL), Frick, and IFOAM - Organics International, Bonn. Version 1.1 of February 08, 2017.

20. Yashalova, N. (2014). Environmental and Economic Priorities of Agriculture in the Transition to a Green Economy // Environmental Economics: an Overview. No 4. pp. 46-56. 